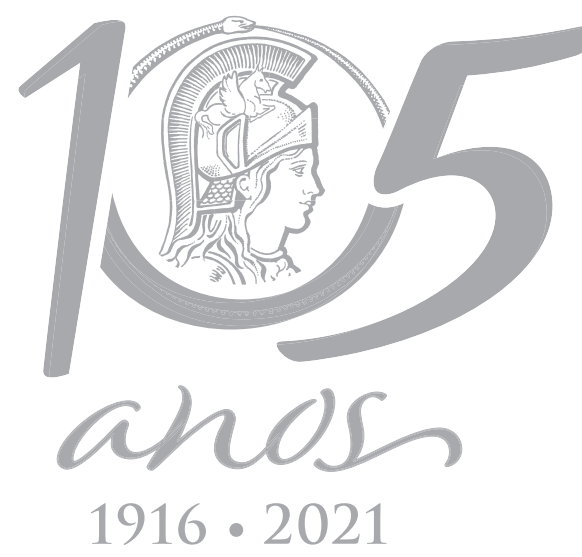

\title{
Anti-Brucella canis antibodies in dogs naturally infected with Leishmania infantum and associated histological alterations in the genital tract
}

\author{
VIVIANE C. BOECHAT, SANDRO A. PEREIRA, ARTUR A.V. MENDES JÚNIOR, ACÁCIA \\ F. VICENTE, JANE MEGID, MAURÍCIO G. DASSO, ROGERIO O. RODRIGUES, LUCIANA \\ F.C. MIRANDA, FABIANO B. FIGUEIREDO, LUIZ C. FERREIRA, RAYANE TELES-DE- \\ FREITAS, RAFAELA V. BRUNO \& RODRIGO C. MENEZES
}

\begin{abstract}
In canine visceral leishmaniasis, coinfections can aggravate the disease. Our aim was to investigate Brucella canis in dogs infected with Leishmania infantum. One hundred and six L. infantum-seropositive dogs were submitted to serology for B. canis, PCR for B. canis and L. infantum, and histopathological analysis of the genital tract. Anti-B. canis antibodies were detected in seven dogs whose clinical signs, L. infantum load and histological alterations were similar to those of seronegative animals. The circulation of anti-B. canis antibodies was low but demonstrates the exposure of dogs to this bacterium in a visceral leishmaniasis-endemic area.
\end{abstract}

Key words: canine brucellosis, canine visceral leishmaniasis, histopathology, PCR, serology.

\section{INTRODUCTION}

Brucella canis is the main causative agent of canine brucellosis, a worldwide zoonotic disease. Transmission occurs by the venereal route and through contact of broken skin or mucosae with or ingestion of contaminated tissue or body fluids such as aborted fetuses, placenta and reproductive secretions. This bacterium can cause late abortion, as well as endometritis, epididymitis, prostatitis, and orchitis in dogs (Hollett 2006, Rodrigues et al. 2016).

The protozoan Leishmania infantum is the causative agent of canine visceral leishmaniasis $(\mathrm{CVL})$, a zoonosis with a worldwide distribution whose main reservoir in urban areas is the dog (Oliveira et al. 2017). Despite the classical transmission of the parasite by the bite of infected phlebotomine sand flies, venereal and vertical transmission between dogs has been reported (Turchetti et al. 2014). Infection with L. infantum can cause orchitis, epididymitis, prostatitis, vaginitis, and endometritis (Boechat et al. 2020).

Coinfections of L. infantum with other pathogens can induce progression of the disease and increase mortality due to CVL (Toepp et al. 2019). However, the circulation of B. canis in dogs infected with L. infantum and the effects of this coinfection on the aggravation of CVL and canine brucellosis are unknown. Therefore, the aims of this study were to investigate the presence of $B$. canis in dogs naturally infected with L. infantum and their clinical signs, as well as the histological alterations and L. infantum load in the genital tract. 


\section{MATERIALS AND METHODS}

Between January 2013 and December 2016, 106 domiciled dogs (63 males and 43 females) that tested seropositive for $L$. infantum in periodic serological surveys performed by public health services participating in the CVL surveillance and control program were included. The animals were from the municipality of Barra Mansa $\left(22^{\circ} 32^{\prime} 38^{\prime \prime} \mathrm{S}\right.$ and $\left.44^{\circ} 10^{\prime} 15^{\prime \prime} \mathrm{W}\right)$, state of Rio de Janeiro, Brazil, a CVL-endemic area. The included dogs tested seropositive for anti-L. infantum antibodies by the rapid dual-path platform (TR DPP $^{\oplus}$ ) assay and enzyme immunoassay (ELISA), both produced by BioManguinhos (Fiocruz, Rio de Janeiro, Brazil). The procedures of this study were approved by the Ethics Committee on Animal Use (CEUA/Fiocruz; Permit Nos. LW-54/13 and LW-24/17).

After mechanical restraint, the dogs were evaluated clinically by inspection of the skin and mucosae, and palpation of the superficial lymph nodes and abdominal organs. Blood was collected from the dogs by puncture of the cephalic vein and the serum obtained was stored at $-20^{\circ} \mathrm{C}$ for the gel immunodiffusion (AGID) assay using cell wall antigens of $B$. ovis to detect anti-B. canis antibodies. The dogs were then sedated by intramuscular administration of ketamine hydrochloride $(10 \mathrm{mg} / \mathrm{kg})$ and acepromazine maleate $(0.2 \mathrm{mg} / \mathrm{kg})$ and euthanized by intravenous injection of an overdose of sodium thiopental and potassium chloride. During necropsy, tissue samples were collected from the male (right and left epididymis, right and left testes, and prostate) and female genital tract (vulva, vagina, and body of the uterus). Three fragments were collected per tissue: the first fragment was immersed in sterile saline and submitted to parasitological culture for detection of Leishmania; the second fragment was stored at $-20^{\circ} \mathrm{C}$ for subsequent analysis by quantitative polymerase chain reaction ( $q P C R$ ) for the detection of $L$. infantum and Brucella spp. DNA; the third fragment was fixed in 10\% buffered formalin and embedded in paraffin (FFPE) for the diagnosis of Leishmania spp. by immunohistochemical and histopathological techniques and for the detection of $L$. infantum and Brucella spp. DNA by qPCR only in B. canisseropositive dogs from which frozen genital tract samples were not collected.

The AGID assay was carried out using as antigen lipopolysaccharide and soluble proteins extracted from the cell wall of B. ovis strain Reo 198 (TECPAR - Instituto de Tecnologia do Paraná, Curitiba, PR, Brazil) according to manufacturer specifications. The serum samples were double tested and the test was interpreted by an experienced professional to avoid false-positive results.

Parasitological culture, histopathology and immunohistochemistry for the diagnosis of Leishmania spp., as well as qPCR for detection of Brucella spp. and L. infantum DNA and quantification of L. infantum load, were carried out following previously described protocols (Keid et al. 2007, Campos et al. 2017, Oliveira et al. 2017). The L. infantum load was expressed as the natural logarithm of the number of parasite genome equivalents (gEq)/ng.

\section{RESULTS}

Anti-B. canis antibodies were detected in seven (6.6\%) of the 106 dogs examined (Table I). Six of these seven dogs (86\%) exhibited clinical signs compatible with CVL, including lymphadenomegaly (71\%), cutaneous ulcers (71\%), splenomegaly (57\%), alopecia (43\%), onychogryphosis (43\%), skin desquamation (43\%), and thinness (43\%) (Table I). Six of these seven dogs (86\%) tested positive for Leishmania 
Table I. Clinical data, histological alterations and Leishmania infantum positivity and load in the genital tract of seven dogs seropositive for anti-B. canis antibodies between January 2013 and December 2016 (Barra Mansa, Rio de Janeiro, Brazil).

\begin{tabular}{|c|c|c|c|c|c|c|c|}
\hline Dog & Sex & Breed & $\begin{array}{c}\text { Age } \\
\text { (years) }\end{array}$ & Clinical signs & Histological alterations & $\begin{array}{l}\text { Leishmania in } \\
\text { genital tract } \\
\text { (PC, IHC, HP and } \\
\text { qPCR) }\end{array}$ & $\begin{array}{l}\text { L. } \\
\text { infantum } \\
\text { load }^{\mathrm{a}}\end{array}$ \\
\hline 1 & M & Mongrel & 4 & $\begin{array}{l}\text { Thinness, alopecia, } \\
\text { desquamation, } \\
\text { cutaneous ulcers, } \\
\text { lymphadenomegaly, } \\
\text { splenomegaly, } \\
\text { onychogryphosis }\end{array}$ & $\begin{array}{c}\text { Moderate to intense bilateral } \\
\text { granulomatous orchitis, } \\
\text { seminiferous tubule atrophy } \\
\text { and degeneration; moderate to } \\
\text { intense, bilateral granulomatous } \\
\text { epididymitis }\end{array}$ & $\mathrm{T}(+) ; \mathrm{E}(+) ; \mathrm{P}(-)$ & $\begin{array}{l}\mathrm{T}=6.87 \\
\mathrm{E}=6.30\end{array}$ \\
\hline 2 & $M$ & Mongrel & 3 & $\begin{array}{l}\text { Thinness, alopecia, } \\
\text { desquamation, } \\
\text { cutaneous ulcers, } \\
\text { lymphadenomegaly, } \\
\text { splenomegaly, } \\
\text { onychogryphosis }\end{array}$ & $\begin{array}{c}\text { Moderate to intense bilateral } \\
\text { granulomatous orchitis, } \\
\text { seminiferous tubule atrophy } \\
\text { and degeneration; moderate } \\
\text { to intense unilateral } \\
\text { granulomatous epididymitis; mild } \\
\text { lymphoplasmacytic prostatitis with } \\
\text { glandular fibrosis and atrophy }\end{array}$ & $\mathrm{T}(+) ; \mathrm{E}(+) ; \mathrm{P}(+)$ & $\begin{array}{l}T=13.93 \\
E=10.53 \\
P=13.27\end{array}$ \\
\hline 3 & M & Mongrel & 2 & $\begin{array}{l}\text { Lymphadenomegaly, } \\
\text { splenomegaly }\end{array}$ & $\begin{array}{l}\text { Moderate to intense bilateral } \\
\text { granulomatous epididymitis }\end{array}$ & $\mathrm{T}(-) ; \mathrm{E}(+) ; \mathrm{P}(-)$ & NQ \\
\hline 4 & $M$ & Pitbull & 9 & $\begin{array}{l}\text { Cutaneous ulcer, } \\
\text { lymphadenomegaly }\end{array}$ & $\begin{array}{c}\text { Mild bilateral granulomatous } \\
\text { orchitis; moderate to intense } \\
\text { bilateral granulomatous } \\
\text { epididymitis; moderate to intense } \\
\text { lymphoplasmacytic prostatitis with } \\
\text { cysts and glandular fibrosis and } \\
\text { atrophy }\end{array}$ & $\mathrm{T}(+) ; \mathrm{E}(+) ; \mathrm{P}(+)$ & $\begin{array}{l}T=-1.91 \\
E=2.64 ; \\
P=-1.04\end{array}$ \\
\hline 5 & $M$ & Mongrel & 2 & Cutaneous ulcer & Absent & $\mathrm{T}(-) ; \mathrm{E}(-) ; \mathrm{P}(-)$ & $\mathrm{NQ}$ \\
\hline 6 & $\mathrm{~F}$ & Mongrel & 2 & $\begin{array}{l}\text { Thinness, alopecia, } \\
\text { desquamation, } \\
\text { cutaneous ulcers, } \\
\text { lymphadenomegaly, } \\
\text { splenomegaly, } \\
\text { onychogryphosis }\end{array}$ & $\begin{array}{c}\text { Moderate to intense granulomatous } \\
\text { vulvitis; mild non granulomatous } \\
\text { vaginitis; } \\
\text { Endometrial hyperplasia }\end{array}$ & $\begin{array}{c}\mathrm{Vu}(+) ; \mathrm{Va}(+) \\
\mathrm{U}(+)\end{array}$ & $\begin{array}{l}V u=4.73 \\
V a=10.73 \\
U=12.34\end{array}$ \\
\hline 7 & $\mathrm{~F}$ & Mongrel & 3 & Absent & $\begin{array}{c}\text { Moderate to intense granulomatous } \\
\text { vulvitis; mild non granulomatous } \\
\text { vaginitis }\end{array}$ & $\begin{array}{c}\mathrm{Vu}(+) ; \mathrm{Va}(+) ; \mathrm{U} \\
(-)\end{array}$ & NQ \\
\hline
\end{tabular}

$a=L$. infantum load expressed as the natural logarithm of the number of parasite genome equivalents (gEq)/ng; $M=m a l e ; F=$ female; $P C=$ parasitological culture; $I H C=$ immunohistochemistry; $H P=$ histopathology; $q P C R=$ quantitative polymerase chain reaction; $\mathrm{T}=$ testis; $\mathrm{E}=$ epididymis; $\mathrm{P}=$ prostate; $\mathrm{Vu}=$ vulva; $\mathrm{Va}=$ vagina; $\mathrm{U}=$ uterus; $(+)=$ positive for Leishmania in at least one test; $(-)=$ negative in all Leishmania tests; $N Q=$ not quantified. 
in the genital tract by at least one of the diagnostic methods used (Table I). The main histological alterations observed in the seven dogs with anti-B. canis antibodies were granulomatous epididymitis (100\%), vulvitis (100\%), orchitis (75\%), lymphoplasmacytic vaginitis (100\%), and lymphoplasmacytic prostatitis with glandular fibrosis and atrophy (50\%) (Table I and Figure 1).

Quantitative PCR for detection of $L$. infantum and Brucella spp. DNA was performed using genital tract samples from 74 of the 106 dogs included in the study; frozen samples were examined in 70 and FFPE samples in 4. These four dogs were seropositive for B. canis and only FFPE samples of their genital tract were available. In
32 dogs, qPCR was not performed because only FFPE samples of the genital tract were available and the animals were seronegative for $B$. canis.

Among the 74 dogs examined by qPCR, seven were positive (Table I) and 67 (43 males and 24 females) were negative for anti-B. canis antibodies and all tested negative for Brucella spp. DNA by PCR. In the seven dogs positive for anti-B. canis antibodies, the L. infantum load ranged from -1.91 to $13.93 \mathrm{gEq} / \mathrm{ng}$ in the genital organs of four dogs (Table I). In the 67 animals negative for anti-B. canis antibodies, the $L$. infantum load in the genital organs ranged from -2.04 to $18.81 \mathrm{gEq} / \mathrm{ng}$ in testes, from -1.16 to 15.34 $\mathrm{gEq} / \mathrm{ng}$ in the epididymis, from 1.10 to $8.76 \mathrm{gEq} /$
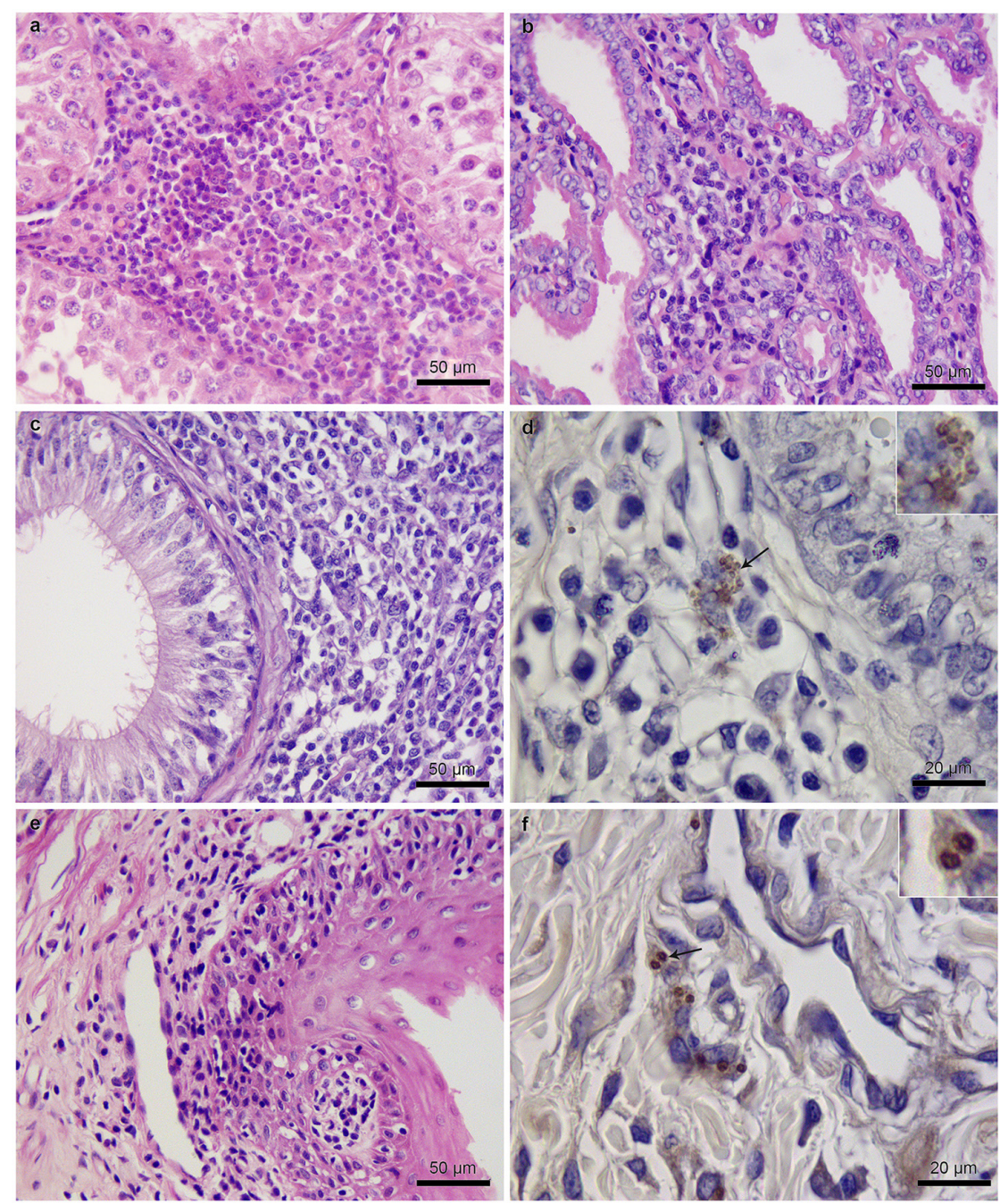

Figure 1. Dogs seropositive for anti-Brucella canis antibodies and infected with Leishmania infantum.

(a) Male \#1. Moderate to intense granulomatous interstitial orchitis. (b to d) Male \#2. (b) Mild lymphoplasmacytic prostatitis. (c) Moderate to intense granulomatous epididymitis. (d) Brownstained amastigote forms of Leishmania in the cytoplasm of macrophages (arrow and inset) in the epididymis. (e to f) Female \#6. (e) Mild vaginitis in the lamina propria and perivascular region consisting of macrophages, lymphocytes and neutrophils. (f) Brown-stained amastigote forms of Leishmania in the cytoplasm of macrophages (arrow and inset) in the vulva. Hematoxylineosin staining (a, b, c, e). Immunohistochemistry $(d, f)$. 
ng in the prostate, from 0.50 to $18.40 \mathrm{gEq} / \mathrm{ng}$ in the vulva, from 1.10 to $16.49 \mathrm{gEq} / \mathrm{ng}$ in the vagina, and from 0.69 to $14.18 \mathrm{gEq} / \mathrm{ng}$ in the uterus.

Considering all dogs with negative anti- $B$. canis antibodies in this study $(n=99,58$ males and 41 females, 67 tested and 32 not tested by qPCR for detection of $L$. infantum and Brucella spp. DNA), 89 (90\%) had clinical signs compatible with CVL. These clinical signs were lymphadenomegaly (53\%), alopecia (46\%), onychogryphosis (45\%), splenomegaly (39\%), skin desquamation (38\%), cachexia (13\%), thinness (13\%), keratoconjunctivitis (12\%), and pale mucosae (4\%). Ninety-two (93\%) of these 99 dogs, 54 males and 38 females, tested positive for Leishmania in the genital tract by at least one of the diagnostic methods used.

Histopathology in these 99 dogs revealed granulomatous inflammation in the vulva (63.4\%), epididymis (60.3\%), testes (51.7\%), vagina $(36.5 \%)$, uterus (14.6\%), and prostate (3.4\%); lymphoplasmacytic inflammation in the prostate $(27.5 \%)$, vagina (14.6\%), vulva (14.6\%), testes $(3.4 \%)$, epididymis (3.4\%), and uterus (2.4\%); seminiferous tubule degeneration (48.2\%) and atrophy (37.9\%) in the testes; fibrosis and glandular atrophy in the prostate (12.0\%), and fibrosis (6.8\%) and necrosis (1.7\%) in the testes.

\section{DISCUSSION}

The detection of anti-B. canis antibodies was low, in agreement with most studies conducted on dogs in Brazil, in which the frequencies of seropositivity ranged from 0.8 to $14 \%$ (Rodrigues et al. 2016). In contrast, few studies found frequencies of seropositivity higher than 20\% in Brazil (Rodrigues et al. 2016). This variation in Brucella seropositivity might be related to the different geographic regions analyzed and the different diagnostic tests used in these studies (AGID, rapid plate agglutination test with and without 2-mercaptoethanol, and tube agglutination test).

A comparative study of serological techniques for the diagnosis of canine brucellosis was conducted on 127 dogs using the results of blood culture, culture of semen/ vaginal swab, and PCR in blood and semen/ vaginal swab as reference standards (Keid et al. 2009). That study demonstrated that, although AGID using the same antigen from the same manufacturer as employed in the present study has limited sensitivity (52.9\%), its specificity is high (100\%). Considering the high specificity of AGID, the negative qPCR result for Brucella spp. in the genital tract of dogs that tested seropositive for this bacterium may be due to the absence of bacteremia, although infection persisted in these dogs (Gordon et al. 1985, Wanke 2004, Keid et al. 2009). Additionally, active infection with this bacterium may have occurred in tissues other than those examined, such as spleen, lymph nodes and intervertebral discs (Hollett 2006). It is also possible that B. canisseropositive dogs did not have active infection, but that anti-B. canis antibodies persisted in blood since the AGID using cell wall antigens can detect these antibodies for up to 4 months after the animal is abacteremic (Wanke 2004).

The AGID using cell wall antigens of $B$. ovis or B. canis and serological tests using B. ovis antigens are considered to have low specificity (Hollett 2006, Cosford 2018), while the AGID used in the present study shows high specificity (Keid et al. 2009). This discrepancy between the results may be related to the use of different protocols and B. ovis strains for antigen production and to the application of different reference standards in the evaluation of specificity of the serological tests (Keid et al. 2009).

Cosford (2018) recommends PCR combined with serology for the detection of $B$. canis because 
of the possibility of false-negative results by culture, which is used as a confirmatory test. Considering the high sensitivity of qPCR (Keid et al. 2009, Hensel et al. 2018) and its combination with AGID in this study, the possibility of falsenegative Brucella spp. results is low in the 67 $B$. canis-seronegative dogs in which qPCR was also performed. However, we cannot rule out the possibility of false-negative results in the 32 B. canis-seronegative dogs that were tested only by AGID due to the low sensitivity of this test (Keid et al. 2009). In these 32 dogs, the use of PCR and culture of blood and/or genital organs would have helped confirm the absence of $B$. canis infection.

Granulomatous inflammation observed in the genital tract is compatible with L. infantum and B. canis infections (Hollett 2006, Boechat et al. 2020). This fact highlights the importance of including canine brucellosis in the differential histological diagnosis of CVL in the genital tract. However, the negative qPCR result for Brucella and detection of $L$. infantum in the genital tract of six of the seven dogs seropositive for $B$. canis suggest that granulomatous inflammation was associated with L. infantum infection. Furthermore, seropositivity for Brucella spp. does not appear to have influenced the frequency and type of clinical signs or L. infantum load since these results were similar in dogs with and without anti-B. canis antibodies. However, the participation of Brucella should not be completely ruled out since the $L$. infantum load in the prostate of one dog seropositive for $B$. canis (13.27 $\mathrm{gEq} / \mathrm{ng}$ ) was higher than that found in the prostate of dogs infected only with $L$. infantum (1.10 to $8.76 \mathrm{gEq} / \mathrm{ng}$ ).

In conclusion, the low frequency of anti-B. canis antibodies and the lack of detection of DNA of this bacterium in the canine population studied suggest that L. infantum infection does not increase the susceptibility to infection with
B. canis. However, seropositivity for B. canis demonstrates the exposure of dogs to this bacterium in a visceral leishmaniasis-endemic area and is an alert to include canine brucellosis in the differential diagnosis of CVL.

\section{Acknowledgments}

We thank the Municipal Health Department of Barra Mansa and the LACEN-RJ for their collaboration; Adilson Almeida, Francisco Rodrigues, Shanna Santos and Monique Campos from INI, Fiocruz, and Vanessa Pelícia from FMVZ, UNESP, for technical assistance, and Ricardo Schmidt from IOC, Fiocruz, for processing the figures. This study was supported by Fundação Carlos Chagas Filho de Amparo à Pesquisa do Estado do Rio de Janeiro (Grants: E-26/203.069/2016, E-26/202.561/2017 and E-26/201.032/2021) and Coordenação de Aperfeiçoamento de Pessoal de Nível Superior (Finance code: 001), Brazil. FBF, JM, SAP and RCM are recipient of productivity fellowships from Conselho Nacional de Desenvolvimento Científico e Tecnológico, Brazil.

\section{REFERENCES}

BOECHAT VC ET AL. 2020. Frequency, active infection and load of Leishmania infantum and associated histological alterations in the genital tract of male and female dogs. PLOS ONE 15: e0238188.

CAMPOS MP, MADEIRA MF, SILVA DA, SOLCÀ MS, ESPÍNDOLA OM, MENDES JÚNIOR AAV \& FIGUEIREDO FB. 2017. Accuracy of quantitative polymerase chain reaction in samples of frozen and paraffin embedded healthy skin for the diagnosis of canine visceral leishmaniasis. Arq Bras Med Vet Zootec 69: 1443-1450.

COSFORD KL. 2018. Brucella canis: An update on research and clinical management. Can Vet J 59: 74-81.

GORDON IC, PUE HL \& RUTGERS HC. 1985. Canine brucellosis in a household. J Am Vet Med Assoc 86: 695-698.

HENSEL ME, NEGRON M \& ARENAS-GAMBOA AM. 2018. Brucellosis in dogs and public health risk. Emerg Infect Dis 24: 1401-1406.

HOLLETT RB. 2006. Canine brucellosis: Outbreaks and compliance. Theriogenology 66: 575-587.

KEID LB, SOARES RM, VASCONCELLOS SA, MEGID J, SALGADO VR \& RICHTZENHAIN LJ. 2009. Comparison of agar gel immunodiffusion test, rapid slide agglutination test, 
microbiological culture and PCR for the diagnosis of canine brucellosis. Res Vet Sci 86: 22-26.

KEID LB, SOARES, RM, VIEIRA NR, MEGID J, SALGADO VR, VASCONCELLOS SA, COSTA M, GREGORI F \& RICHTZENHAIN LJ. 2007. Diagnosis of canine brucellosis: comparison between serological and microbiological tests and a PCR based on primers to 16S-23S rDNA interspacer. Vet Res Commun 31: 951-965.

OLIVEIRA VC ET AL. 2017. Occurrence of Leishmania infantum in the central nervous system of naturally infected dogs: parasite load, viability, co-infections and histological alterations. PLOS ONE 12: e0175588.

RODRIGUES FS, SOUZA GV, MAGALHÃES ILA, COLARES RR \& SANTIAGO SLT. 2016. Brucelose canina: revisão de literatura. Rev Bras Hig Sanid Anim 10: 870-888.

TOEPP AJ ET AL. 2019. Comorbid infections induce progression of visceral leishmaniasis. Parasit Vectors 12: 54.

TURCHETTI AP, SOUZA TD, PAIXÃO TA \& SANTOS RL. 2014. Sexual and vertical transmission of visceral leishmaniasis. J Infect Dev Ctries 8: 403-407.

WANKE MM. 2004. Canine brucellosis. Anim Reprod Sci 82/83: 195-207.

\section{How to cite}

BOECHAT VC ET AL. 2021. Anti-Brucella canis antibodies in dogs naturally infected with Leishmania infantum and associated histological alterations in the genital tract. An Acad Bras Cienc 93: e20201682. DOI 10.1590/0001-3765202120201682.

Manuscript received on October 21, 2020;

accepted for publication on August 10, 2021

\section{VIVIANE C. BOECHAT ${ }^{1}$}

https://orcid.org/0000-0003-0541-6278

SANDRO A. PEREIRA ${ }^{1}$

https://orcid.org/0000-0002-0614-4713

\section{ARTUR A.V. MENDES JÚNIOR ${ }^{1}$}

https://orcid.org/0000-0002-7106-797X

\section{ACÁCIA F. VICENTE ${ }^{2}$}

https://orcid.org/0000-0002-3960-6646

\section{JANE MEGID ${ }^{2}$}

https://orcid.org/0000-0002-6540-7157

MAURÍCIO G. DASSO 3

https://orcid.org/0000-0002-5114-7438

ROGERIO O. RODRIGUES ${ }^{3}$ https://orcid.org/0000-0002-5289-4662

LUCIANA F.C. MIRANDA ${ }^{1}$

https://orcid.org/0000-0002-1695-1922

FABIANO B. FIGUEIREDO 4

https://orcid.org/0000-0001-6861-0997

\section{LUIZ C. FERREIRA ${ }^{1}$}

https://orcid.org/0000-0002-9312-4656

\section{RAYANE TELES-DE-FREITAS ${ }^{5}$}

https://orcid.org/0000-0003-2613-0631

\section{RAFAELA V. BRUNO ${ }^{5,6}$}

https://orcid.org/0000-0002-7082-9768

\section{RODRIGO C. MENEZES ${ }^{1}$}

https://orcid.org/0000-0003-1853-3449

${ }^{1}$ Instituto Nacional de Infectologia Evandro Chagas, Fundação Oswaldo Cruz, Av. Brasil, 4365, 21040-360 Rio de Janeiro, RJ, Brazil

${ }^{2}$ Universidade Estadual Paulista Júlio de Mesquita Filho, Departamento de Higiene Veterinária e Saúde Pública, Rua Professor Doutor Walter Mauricio Correa, s/n, 18618-681 Botucatu, SP, Brazil

${ }^{3}$ Instituto de Pesquisas Veterinárias Desidério Finamor, Laboratório de Brucelose, Estrada Municipal do Conde, 6000, 92990-000 Eldorado do Sul, RS, Brazil

${ }^{4}$ Instituto Carlos Chagas, Fundação Oswaldo Cruz, Rua Professor Algacyr Munhoz Mader, 3775, 81350-010 Curitiba, PR, Brazil

${ }^{5}$ Instituto Oswaldo Cruz, Fundação Oswaldo Cruz, Av. Brasil, 4365, 21040-360 Rio de Janeiro, RJ, Brazil

${ }^{6}$ Universidade Federal do Rio de Janeiro, Instituto Nacional de Ciência e Tecnologia em Entomologia Molecular, Av. Carlos Chagas Filho, 373, 21941-902 Rio de Janeiro, RJ, Brazil

Correspondence to: Rodrigo C. Menezes

E-mail:rodrigo.menezes@ini.fiocruz.br

\section{Author contributions}

VCB and RCM conceived and designed the study; VCB, RCM, AAVMJ, AFV, LFCM, LCF, JM, MGD, ROR, RTF and RVB performed the experiments; VCB and RCM analyzed the data; VCB, RCM, SAP and FBF wrote the manuscript; RCM, FBF and SAP secured funding and resources; RCM supervised the study; all authors read and approved the final manuscript. 